\title{
The Impact of Cause-Related Marketing Strategies on Switching Intentions: An Applied Study on Private Education Service
}

\author{
Mona Abdelreheem, Mohamed A. Ragheb, Passent Tantawi \\ The Arab Academy for Science and Technology \& Maritime Transport, Alexandria, Egypt \\ Email: mayyegouda@gmail.com
}

How to cite this paper: Abdelreheem, M., Ragheb, M.A. and Tantawi, P. (2021) The Impact of Cause-Related Marketing Strategies on Switching Intentions: An Applied Study on Private Education Service. Open Access Library Journal, 8: e7489.

https://doi.org/10.4236/oalib.1107489

Received: May 4, 2021

Accepted: July 9, 2021

Published: July 12, 2021

Copyright $\odot 2021$ by author(s) and Open Access Library Inc.

This work is licensed under the Creative Commons Attribution International License (CC BY 4.0).

http://creativecommons.org/licenses/by/4.0/

\section{(c) (i) Open Access}

\begin{abstract}
This study investigated the relationship between the CRM strategies, brand equity, brand image, brand awareness, brand association, brand loyalty, perceived quality, and switching intentions. This research depended on the deductive approach to collecting data. The researcher used the method of survey questionnaires through simple random sampling technique to collect primary data that are used to achieve the purpose of the study, which is to study the relationship between the CRM strategies, brand equity, brand image, brand awareness, brand association, brand loyalty, perceived quality, and switching intentions of AASTMT undergraduates and postgraduate's students. The study found there was a significant relationship between CRM Strategies and switching intentions.
\end{abstract}

\section{Subject Areas}

Marketing, Marketing Theory and Applications

\section{Keywords}

CRM Strategies, Brand Association, Perceived Quality and Switching Intentions

\section{Introduction}

Over the last decade, corporate social responsibility (CSR) has become a fundamental strategic priority for businesses [1]. CSR refers to the idea that corporations should take responsibility not only for the economic consequences of op- 
erating a business but also for any impacts that the business has on social and environmental issues (Australian Human Rights Commission, 2008).

CRM has mainly been studied from Western countries' perspectives [2]. Such research is lacking in non-intensive research cultures of the Arab world. Hence, understanding the Egyptian case is of vital importance to capture an idea about the Middle Eastern perspective on CRM strategies. The primary aim of any marketing communications strategy including CRM is to develop brand attitude and enhance purchase intention [3] [4]. The successful marketing communication in reaching those objectives can be impacted by the consumer's attitude to the communication itself [5] [6]. In that regard, CRM is targeting consumers with high interest in corporate social responsibility [7] [8]. Researches have indicated that consumers have a positive view of both CRM and the companies that engage in this strategy [9] [10]. Further, it is important to understand whether this strategy is likely to be more effective than traditional communications techniques for achieving the critical objectives of improved brand attitude and purchase intention.

\section{Literature Review}

Corporate Social Responsibility (CSR) is a concept that was introduced by B.R. Howard over 60 years ago in his controversial book The Social Responsibilities of Businessmen (1953). This section will examine the following Hypothesis through previous studies;

H1: CRM strategies have a direct influence on the Behavior Intention of the student.

H2: CRM Strategies influence the Brand Equity Dimensions.

H2.1: CRM Strategies influence the Brand Image.

H2.2: CRM Strategies influence the Brand Awareness.

H2.3: CRM Strategies influence the Brand Association.

H2.4: CRM Strategies influence the Brand Loyalty.

H2.5: CRM Strategies influence the Perceived Quality.

H3: Brand Equity Dimensions influence the Student Switching Intention.

H3.1: Brand Image influence the Student Switching Intention.

H3.2: Brand Awareness influence the Student Switching Intention.

H3.3: Brand Association influence the Student Switching Intention.

H3.4: Brand Loyalty influence the Student Switching Intention.

H3.5: Perceived Quality influence the Student Switching Intention.

\subsection{The Relationship between CRM Strategies and the Behavioral Intentions of the Students}

This section investigates the relation between CRM Strategies (Sponsorshiplinked marketing, Transaction-based CRM, cause-related "event" marketing and cause-related "experiential" marketing).

The relation between cause-related marketing and behavioral intention in $\mathrm{Pa}$ - 
kistan was examined. In addition, the researchers investigated the moderating impact of both brand awareness and corporate image in the above relation. The researchers collected primary data. A survey was conducted and distributed among students who studied at various universities located in Rawalpindi and Islamabad. The final sample consisted of 203 university's students. The hypotheses were tested by the correlation and regression analysis. Results proved that the behavioral intention of the customers was influenced by the CRM campaigns. In addition, the moderating effect of brand awareness and corporate image was proved in the relation between CRM and behavioral intention. Finally, the researchers suggested for future studies to collect the data from other universities located on other cities in Pakistan than Rawalpindi and Islamabad to see if the same results will be concluded or no, by that the results could be generalized [11].

The influence of cause related marketing on customer's behavior and purchase intention was investigated. To reach this aim, the researchers collected the data of the variables through utilizing a questionnaire. This questionnaire targeted the undergraduate business students who had enrolled at a major university located in Spain. The total participants in this questionnaire were $186 \mathrm{stu}-$ dents. MANCOVA was utilized to analyze the collected data. The findings proved that CRM has a significant influence on both of behavior and purchase intention of the customer. Finally, the researchers saw that the finding of their research was useful for marketers as it provides them with useful guidelines in designing their cause-related marketing initiatives [12].

In the shade of the competitive market that are characterized by products, which are similar in services, quality and prices. Corporate always tries to behave as a good citizen, this will help the corporate in increasing its opportunity to be highlighted between its competitors. In addition, this provides a distinguish in its brand and products among other choices. The influence of CRM (cause-related marketing) on each of behavioral intention, brand attitudes and advertising in Iran was examined. Moreover, the researcher investigated the mediating role of cause involvement and skepticism in the above relation. Semi-experimental design was conducted in this research through utilizing two structured questionnaires. The two questionnaires were distributed among experimental groups and control groups, with total responses of 483 participants from Tehran. Covariance analysis was utilizing in analyzing the data. The results assured that there is a significant effect of CRM on the customer behavioral intention and attitude toward brand and advertising. Finally, the moderating effect of skepticism was proved, while the moderating effect of cause involvement was not proved [13].

Recently, Cause Related Marketing had gained an increasing popularity as a used tool by companies. CRM represents a creative manner of partnership between companies and nonprofit organization. Brand makers usually use the CRM strategies as they believe in the ability of these strategies to improve the purchase intention. Therefore, examining the role of CRM in enhancing the 
purchase intention. The researchers targeted the context of local fashion brands in Indonesia. An online questionnaire was done, with a final sample of 212 responses. Simple regression analysis was used to analyze the gathered data. Finally, the results indicated a significant impact of Cause Related Marketing on purchase intention [14].

From the previous studies, first hypothesis of the study can be concluded that there is a significant relation between CRM Strategies and the student switching intentions.

H1: There is a Significant Relation between CRM Strategies and the Student Switching Intentions.

\subsection{The Relationship between CRM Strategies and Brand Characteristics (Brand Equity, Brand Image, Brand Awareness, Brand Association, Brand Loyalty and Perceived Quality)}

This section investigates the relation between CRM Strategies (Sponsorshiplinked marketing, Transaction-based CRM, cause-related "event" marketing and cause-related "experiential" marketing) and the Brand characteristics (Brand Equity, Brand Image, Brand Awareness, Brand Association, Brand Loyalty and Perceived Quality).

The relation between CRM and brand equity and their influence on purchase intention in Iran was studied. Quantitative survey was done to collect data regarding the research variables. This survey was distributed among consumers studying in different purchase centers located in Esfahan, Iran. The final sample consisted of 384 surveys. The hypotheses were tested by using structural equation modeling. The results proved that CRM has a significant relation with brand equity dimensions and cultural values. Moreover, the purchase intentions of consumer are affected by the campaigns of CRM. Researchers suggested for future researches to be done in other cities in Iran to see if the sample results will be concluded and by that could be generalized [15].

The influence of CRM on brand image, multinational corporate reputation and purchase intention was investigated. The researchers made a comparative study between Indonesia and Thailand, depending on collecting primary data. This primary data was utilized by making a survey, where the final sample consisted of 113 surveys from both countries. After analyzing the data, the results indicated a positive impact of CRM on brand image and multinational corporate reputation as well as on purchase intention [16].

The influence of sponsorship-linked marketing activities on the perceived consumer-based brand equity was examined. The perceived consumer-based brand equity was measured in this research by many elements, which are: perceived quality, brand loyalty, brand experience, brand awareness and brand associations. To collect data about the research variables, the researchers depended on a case study. This case study determined how sponsorship-linked marketing strategy was adopted inside a Chinese company for sports apparel and equip- 
ment named "Li Ning Company Limited". The gathered data was analyzed and the findings indicated a direct influence of sponsorship-linked marketing activities on each of perceived quality, brand loyalty and brand experience, but not on the level of sports involvement [17].

H2.1: There is a Significant Relation between CRM Strategies and the Brand Equity

H2.2: There is a Significant Relation between CRM Strategies and the Brand Image.

H2.3: There is a Significant Relation between CRM Strategies and the Brand Awareness.

H2.4: There is a Significant Relation between CRM Strategies and the Brand Association.

H2.5: There is a Significant Relation between CRM Strategies and the Brand Loyalty.

H2.6: There is a Significant Relation between CRM Strategies and the Perceived Quality.

\subsection{The Relationship between Brand Characteristics and Student Switching}

This section investigates the relation between the Brand Characteristics (Brand Equity, Brand Image, Brand Awareness, Brand Association, Brand Loyalty and Perceived Quality) on buying intention.

The relationship between brand equity, purchase and switching intention and brand preference from Iranian young consumers' viewpoint was investigated. Data were collected from Iranian students' who were the owners of selected brand of laptop and mobile phone. Structural equation modeling was applied in LISREL and subgroup correlation analysis in SPSS for data analysis. The results indicated that brand equity positively affected on consumers' brand preference and purchase intention [18].

The impact of interpersonal influences, brand origin and brand image on purchase and switching intentions was clarified. The data were collected using a structured questionnaire focusing on the normative and informational interpersonal influences, brand origin and brand image affecting purchase intentions. The final questionnaire was distributed to respondents in the Greater London in the UK and Mumbai in India. More than 900 consumers were contacted in each country, resulting in a final usable sample of 277 in the United Kingdom and 291 in India. The results found that there was a positive and significant relationship between interpersonal influences, brand origin and brand image on purchase and switching intentions [19].

The impact of brand equity, perceived quality, brand awareness, brand associations and brand loyalty on the consumer responses, purchase intention, brand extension, willingness to pay a higher price and brand preferences was examined. The data were collected using a convenience sampling method from the 
stores and customers of Sony. Sampling was conducted using convenient method, with sample size 384. A survey questionnaire was conducted. The results found that the perceived quality had an effect of creation of brand equity, and brand equity had the highest effect on purchase and behavioral intention [20].

The effect of brand association, brand loyalty, brand awareness, brand image and brand equity among young consumers on behavioral and purchase intentions was illustrated. The data were collected from 200 young consumers and analyzed using descriptive, correlation and multiple regression analysis via statistical package. The findings found that there was a positive and significant impact of brand association, brand loyalty, brand awareness, brand image and brand equity on behavioral and purchase intentions [21].

H3.1: There is a Significant Relation between Brand Equity and Student Switching Intentions.

H3.2: There is a Significant Relation between Brand Image and Student Switching Intentions.

H3.3: There is a Significant Relation between Brand Awareness and Student Switching Intentions.

H3.4: There is a Significant Relation between Brand Association and Student Switching Intentions.

H3.5: There is a Significant Relation between Brand Loyalty and Student Switching Intentions.

H3.6: There is a Significant Relation between Perceived Quality and Student Switching Intentions.

\section{Research Methodology}

In this section, the researcher explains the research methodology adopted in this study. This research depended on the deductive approach to collecting data. The researcher used the method of survey questionnaires through simple random sampling technique to collect primary data that are used to achieve the purpose of the study, which is to study the relationship between the CRM strategies, brand equity, brand image, brand awareness, brand association, brand loyalty, perceived quality, and switching intentions of AASTMT undergraduates and postgraduate's students (Figure 1). The survey was 8 pages divided into 3 . The first section had four scenarios applied of the four CrM strategies. Each scenario had 9 questions of 7 Likert scale; hence, 36 questions of the survey were related to sponsorship-linked marketing, transaction-based CrM, cause-related "event" marketing and cause-related "experiential" marketing. Attitude toward the strategy was measured using a modification of a 9-item, 7-point semantic differential rating scale (Burton and Lichtenstein 1988; Lichtenstein and Bearden 1989). The scale uses the following anchors in response to the statement "My attitude toward this deal is": favorable/unfavorable, bad/good, harmful/beneficial, attractive/unattractive, poor/excellent. The final item has the anchors of strongly disagree/strongly agree in response to the statement "I like this deal". For this 


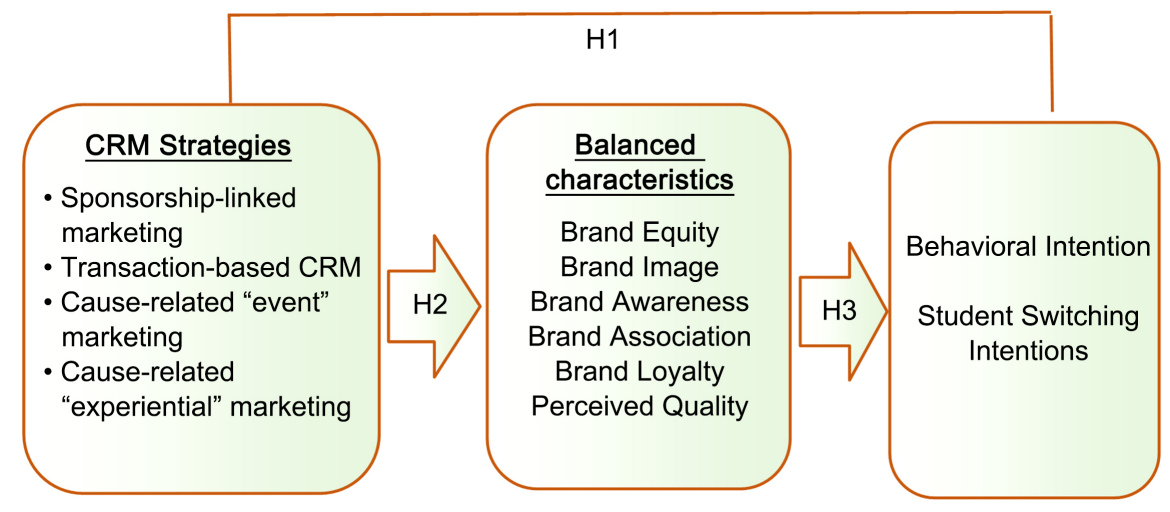

Figure 1. Research framework.

study, the first two statements were changed to: "My attitude toward this marketing campaign is..." and "I like this marketing campaign." In addition, the anchors attractive/unattractive were reversed to be consistent with the other items. Finally, a 7-point scale was used to be consistent with most of the items in the survey. The aim of this section is to examine if students switching/purchasing intentions are impacted by CRM strategies. The second section had 44 questions of 5 Likert scale regarding the brand equity, brand image, brand loyalty, perceived value, brand association, and brand awareness. The scales dimensions are illustrated in the survey, refer to the appendix. Finally, the third section included demographic questions such as: age, income level, and higher completed education level. The sample size is appropriate to this paper and matches the statistical computations required for estimating quantitative research samples. A total of 405 of completed and valid survey responses were collected.

\subsection{Variables and Measurement}

The variables used in this study can be categorized into two main types which are; the dependent and independent variables.

\subsubsection{Dependent Variable}

Student Switching Intentions and Behavioral Intention (Keller, 2008; Yoo and Donthu, 2001).

\subsubsection{Independent Variable}

CRM Strategies (Sponsorship-linked marketing, Transaction-based CRM, causerelated "event" marketing and cause-related "experiential" marketing) (Burton and Lichtenstein 1988; Lichtenstein and Bearden 1989).

\subsubsection{Moderating Variables}

Brand characteristics;

- Brand Equity (yoo et al., 2001)

- Brand Image (Keller, 2001; Aaker, 1996; Vazquez et al., 2002)

- Brand Awareness (yoo et al., 2001; Buil et al., 2008; Aaker, 1996; Keller, 2001)

- Brand Association (Evans et al., 2006; Buil et al., 2008). 
- Brand Loyalty (Keller, 2001; Ballester et al., 2003)

- Perceived Quality (Stevens et al., 1995).

\section{Research Analysis and Findings}

This chapter introduces the empirical study for the relationship between CRM Strategies and Behavioral Intention with the mediation role of Brand Equity, Brand Image, Brand Loyalty, Brand Association, Brand Awareness, and Perceived Quality.

\subsection{The First Hypothesis: The Relationship between CRM Strategies; Sponsorship-Linked Marketing, Transaction-Based CRM, Cause-Related Experiential Marketing, and Cause-Related Event Marketing on Behavioral Intention}

This section investigates the relationship between CRM Strategies; Sponsorship-Linked Marketing, Transaction-Based CRM, Cause-Related Experiential Marketing, and Cause-Related Event Marketing on Behavioral Intention. As the formal and informal tests shows that data under study are not normally distributed, Spearman's correlation coefficient is used. According to validity and reliability test of the research variables, it could be noticed that the data showed Kaiser-Meyer-Olkin measure of sampling adequacy (KMO) greater than 0.5, which was considered to be good, and a significant Bartlett's Sphericity test. The average variance extracted (AVE) was found to be more than 50\%. Also, all Cronbach's alpha values are greater than 0.7 . The values obtained implied an adequate convergent validity as well as an adequate reliability.

According to, the formal testing of normality assumption using Kolmogorov-Smirnov test of normality for the research variables, it could be observed that the research variables are not normally distributed, as the corresponding P-values are all less than 0.05 . The informal test of normality, where it could be shown that some of the skewness and kurtosis values are beyond the accepted level of \pm 1 , which means that the data under study are not approximately normal. Consequently, non-parametric tests are used to describe the relationships between the research variables.

The correlation matrix for the relationship between CRM Strategies; Sponsorship-Linked Marketing, Transaction-Based CRM, Cause-Related Experiential Marketing, Cause-Related Event Marketing, and Behavioral Intention. It was observed that:

There is a significant relationship between Sponsorship-Linked Marketing and Behavioral Intention, as the corresponding P-value is less than 0.05 ( $\mathrm{P}$-value $=$ 0.000). Also, there is a positive moderate relationship between Sponsorship-Linked Marketing and Behavioral Intention, as the corresponding correlation coefficient lies between 0.3 and $0.6(\mathrm{r}=0.342)$.

There is a significant relationship between Transaction-Based CRM and Behavioral Intention, as the corresponding $\mathrm{P}$-value is less than $0.05(\mathrm{P}$-value $=$ 
0.000). Also, there is a positive relationship between Transaction-Based CRM and Behavioral Intention, as the corresponding correlation coefficient lies between 0.3 and $0.6(\mathrm{r}=0.239)$.

There is a significant relationship between Cause-Related Event Marketing and Behavioral Intention, as the corresponding $\mathrm{P}$-value is less than 0.05 ( $\mathrm{P}$-value $=0.000)$. Also, there is a positive moderate relationship between Cause-Related Event Marketing and Behavioral Intention, as the corresponding correlation coefficient lies between 0.3 and $0.6(\mathrm{r}=0.283)$.

There is a significant relationship between Cause-Related Experiential Marketing and Behavioral Intention, as the corresponding $\mathrm{P}$-value is less than 0.05 $(\mathrm{P}$-value $=0.000)$. Also, there is a positive moderate relationship between CauseRelated Experiential Marketing and Behavioral Intention, as the corresponding correlation coefficient lies between 0.3 and $0.6(\mathrm{r}=0.337)$.

Table 1 shows the SEM analysis for the impact of the CRM Strategies; Sponsorship-Linked Marketing, Transaction-Based CRM, Cause-Related Experiential Marketing, and Cause-Related Event Marketing on Behavioral Intention. It could be observed that:

There is a significant impact of Cause-Related Experiential Marketing on Behavioral Intention, as the corresponding $\mathrm{P}$-value is less than 0.05 ( $\mathrm{P}$-value = 0.000). Also, there is a positive impact of Cause-Related Experiential Marketing on Behavioral Intention, as the corresponding estimate is greater than zero (Estimate $=0.243$ ).

There is an insignificant impact of Sponsorship-Linked Marketing on Behavioral Intention, as the corresponding $\mathrm{P}$-value is greater than 0.05 ( $\mathrm{P}$-value $=$ 0.092).

There is an insignificant impact of Cause-Related Event Marketing on Behavioral Intention, as the corresponding $\mathrm{P}$-value is greater than 0.05 ( $\mathrm{P}$-value $=$ 0.403).

There is an insignificant impact of Transaction-Based CRM on Behavioral Intention, as the corresponding $\mathrm{P}$-value is greater than $0.05(\mathrm{P}$-value $=0.406)$.

Furthermore, the R square is 0.199 , which means $19.9 \%$ of the variation in the Behavioral Intention can be explained by the CRM Strategies.

Therefore, H1 "CRM Strategies has a direct influence on Behavioral Intention" is partially supported.

Table 1. SEM analysis of CRM strategies on behavioral intention.

\begin{tabular}{lccccc}
\hline & & & Estimate & $\mathrm{P}$ & $\mathrm{R}^{2}$ \\
\hline Behavioral Intention & $<---$ & Cause-Related Experiential Marketing & 0.243 & $* * *$ \\
Behavioral Intention & $<---$ & Sponsorship-Linked Marketing & 0.174 & 0.092 \\
Behavioral Intention & $<---$ & Cause-Related Event Marketing & 0.064 & 0.403 & 0.199 \\
Behavioral Intention & $<---$ & Transaction-Based CRM & -0.047 & 0.406
\end{tabular}




\subsection{The Second Hypothesis: The Relationship between CRM Strategies and Brand Equity, Brand Image, Brand Awareness, Brand Association, Brand Loyalty, and Perceived Quality}

This section investigates the relationship between CRM Strategies; Sponsorship-Linked Marketing, Transaction-Based CRM, Cause-Related Experiential Marketing, Cause-Related Event Marketing and Brand Equity, Brand Image, Brand Awareness, Brand Association, Brand Loyalty, and Perceived Quality. The correlation matrix for the relationship between CRM Strategies; SponsorshipLinked Marketing, Transaction-Based CRM, Cause-Related Experiential Marketing, Cause-Related Event Marketing, and Brand Equity. It was observed that:

There is a significant relationship between Sponsorship-Linked Marketing and Brand Equity, as the corresponding P-value is less than 0.05 ( $\mathrm{P}$-value $=0.000$ ). Also, there is a positive moderate relationship between Sponsorship-Linked Marketing and Brand Equity, as the corresponding correlation coefficient lies between 0.3 and $0.6(\mathrm{r}=0.366)$.

There is a significant relationship between Transaction-Based CRM and Brand Equity, as the corresponding P-value is less than 0.05 ( $\mathrm{P}$-value $=0.000)$. Also, there is a positive relationship between Transaction-Based CRM and Brand Equity, as the corresponding correlation coefficient lies between 0.3 and $0.6(r=0.337)$.

There is a significant relationship between Cause-Related Event Marketing and Brand Equity, as the corresponding P-value is less than 0.05 ( $\mathrm{P}$-value $=0.000)$. Also, there is a positive moderate relationship between Cause-Related Event Marketing and Brand Equity, as the corresponding correlation coefficient lies between 0.3 and $0.6(\mathrm{r}=0.310)$.

There is a significant relationship between Cause-Related Experiential Marketing and Brand Equity, as the corresponding P-value is less than 0.05 (P-value $=0.000)$. Also, there is a positive moderate relationship between Cause-Related Experiential Marketing and Brand Equity, as the corresponding correlation coefficient lies between 0.3 and $0.6(r=0.397)$.

Table 2 shows the SEM analysis for the impact of the CRM Strategies; Sponsorship-Linked Marketing, Transaction-Based CRM, Cause-Related Experiential Marketing, and Cause-Related Event Marketing on Brand Equity. It could be observed that:

Table 2. The SEM analysis of CRM strategies on brand equity.

\begin{tabular}{cccccc}
\hline & & & Estimate & $\mathrm{P}$ & $\mathrm{R}^{2}$ \\
\hline Brand Equity & $<---$ & Cause-Related Experiential Marketing & 0.172 & 0.006 & \\
Brand Equity & $<---$ & Sponsorship-Linked Marketing & 0.206 & 0.040 & \\
Brand Equity & $<---$ & Cause-Related Event Marketing & -0.007 & 0.928 & \\
Brand Equity & $<---$ & Transaction-Based CRM & 0.038 & 0.489 & \\
\hline
\end{tabular}


There is a significant impact of Cause-Related Experiential Marketing on Brand Equity, as the corresponding $\mathrm{P}$-value is less than 0.05 ( $\mathrm{P}$-value $=0.006$ ). Also, there is a positive impact of Cause-Related Experiential Marketing on Brand Equity, as the corresponding estimate is greater than zero (Estimate $=0.172$ ).

There is a significant impact of Sponsorship-Linked Marketing on Brand Equity, as the corresponding $\mathrm{P}$-value is less than $0.05(\mathrm{P}$-value $=0.040)$. Also, there is a positive impact of Cause-Related Experiential Marketing on Brand Equity, as the corresponding estimate is greater than zero (Estimate $=0.206$ ).

There is an insignificant impact of Cause-Related Event Marketing on Brand Equity, as the corresponding $\mathrm{P}$-value is greater than 0.05 ( $\mathrm{P}$-value $=0.928$ ).

There is an insignificant impact of Transaction-Based CRM on Brand Equity, as the corresponding $\mathrm{P}$-value is greater than $0.05(\mathrm{P}$-value $=0.489)$.

Furthermore, the R square is 0.204 , which means $20.5 \%$ of the variation in the Brand Equity can be explained by the CRM Strategies.

Therefore, H2.1 "CRM Strategies influence the Brand Equity" is partially supported.

The correlation matrix for the relationship between CRM Strategies; Sponsorship-Linked Marketing, Transaction-Based CRM, Cause-Related Experiential Marketing, Cause-Related Event Marketing, and Brand Image. It was observed that:

There is a significant relationship between Sponsorship-Linked Marketing and Brand Image, as the corresponding $\mathrm{P}$-value is less than $0.05(\mathrm{P}$-value $=0.000)$. Also, there is a positive moderate relationship between Sponsorship-Linked Marketing and Brand Image, as the corresponding correlation coefficient lies between 0.3 and $0.6(r=0.331)$.

There is a significant relationship between Transaction-Based CRM and Brand Image, as the corresponding $\mathrm{P}$-value is less than $0.05(\mathrm{P}$-value $=0.000)$. Also, there is a positive relationship between Transaction-Based CRM and Brand Image, as the corresponding correlation coefficient lies between 0.3 and $0.6(r=0.304)$.

There is a significant relationship between Cause-Related Event Marketing and Brand Image, as the corresponding $\mathrm{P}$-value is less than 0.05 (P-value = 0.000). Also, there is a positive moderate relationship between Cause-Related Event Marketing and Brand Image, as the corresponding correlation coefficient lies between 0.3 and $0.6(r=0.291)$.

There is a significant relationship between Cause-Related Experiential Marketing and Brand Image, as the corresponding P-value is less than 0.05 (P-value $=0.000)$. Also, there is a positive moderate relationship between Cause-Related Experiential Marketing and Brand Image, as the corresponding correlation coefficient lies between 0.3 and $0.6(\mathrm{r}=0.348)$.

Table 3 shows the SEM analysis for the impact of the CRM Strategies; Sponsorship-Linked Marketing, Transaction-Based CRM, Cause-Related Experiential Marketing, and Cause-Related Event Marketing on Brand Image. It could be observed that: 
Table 3. SEM analysis of CRM strategies on brand image.

\begin{tabular}{cccccc}
\hline & & & Estimate & $\mathrm{P}$ & $\mathrm{R}^{2}$ \\
\hline Brand Image & $<---$ & Cause-Related Experiential Marketing & 0.206 & 0.001 & \\
Brand Image & $<---$ & Sponsorship-Linked Marketing & 0.160 & 0.116 & \\
Brand Image & $<---$ & Cause-Related Event Marketing & -0.012 & 0.876 & 0.171 \\
Brand Image & $<---$ & Transaction-Based CRM & 0.036 & 0.514 & \\
\hline
\end{tabular}

There is a significant impact of Cause-Related Experiential Marketing on Brand Image, as the corresponding $\mathrm{P}$-value is less than 0.05 ( $\mathrm{P}$-value $=0.001)$. Also, there is a positive impact of Cause-Related Experiential Marketing on Brand Image, as the corresponding estimate is greater than zero (Estimate $=0.206$ ).

There is an insignificant impact of Sponsorship-Linked Marketing on Brand Image, as the corresponding $\mathrm{P}$-value is greater than 0.05 ( $\mathrm{P}$-value $=0.116$ ).

There is an insignificant impact of Cause-Related Event Marketing on Brand Image, as the corresponding $\mathrm{P}$-value is greater than 0.05 ( $\mathrm{P}$-value $=0.876$ ).

There is an insignificant impact of Transaction-Based CRM on Brand Image, as the corresponding $\mathrm{P}$-value is greater than $0.05(\mathrm{P}$-value $=0.514)$.

Furthermore, the R square is 0.171 , which means $17.1 \%$ of the variation in the Brand Image can be explained by the CRM Strategies.

Therefore, H2.2 "CRM Strategies influence the Brand Image" is partially supported.

The correlation matrix for the relationship between CRM Strategies; Sponsorship-Linked Marketing, Transaction-Based CRM, Cause-Related Experiential Marketing, Cause-Related Event Marketing, and Brand Awareness. It was observed that:

There is a significant relationship between Sponsorship-Linked Marketing and Brand Awareness, as the corresponding P-value is less than 0.05 (P-value $=$ 0.000). Also, there is a positive moderate relationship between Sponsorship-Linked Marketing and Brand Awareness, as the corresponding correlation coefficient lies between 0.3 and $0.6(\mathrm{r}=0.379)$.

There is a significant relationship between Transaction-Based CRM and Brand Awareness, as the corresponding $\mathrm{P}$-value is less than 0.05 ( $\mathrm{P}$-value $=0.000)$. Also, there is a positive relationship between Transaction-Based CRM and Brand Awareness, as the corresponding correlation coefficient lies between 0.3 and 0.6 $(\mathrm{r}=0.335)$.

There is a significant relationship between Cause-Related Event Marketing and Brand Awareness, as the corresponding $\mathrm{P}$-value is less than 0.05 ( $\mathrm{P}$-value = 0.000). Also, there is a positive moderate relationship between Cause-Related Event Marketing and Brand Awareness, as the corresponding correlation coefficient lies between 0.3 and $0.6(\mathrm{r}=0.337)$.

There is a significant relationship between Cause-Related Experiential Mar- 
keting and Brand Awareness, as the corresponding P-value is less than 0.05 (P-value $=0.000)$. Also, there is a positive moderate relationship between Cause-Related Experiential Marketing and Brand Awareness, as the corresponding correlation coefficient lies between 0.3 and $0.6(r=0.375)$.

Table 4 shows the SEM analysis for the impact of the CRM Strategies; Sponsorship-Linked Marketing, Transaction-Based CRM, Cause-Related Experiential Marketing, and Cause-Related Event Marketing on Brand Awareness. It could be observed that:

There is an insignificant impact of Cause-Related Experiential Marketing on Brand Awareness, as the corresponding $\mathrm{P}$-value is greater than $0.05(\mathrm{P}$-value $=$ 0.070 ).

There is an insignificant impact of Sponsorship-Linked Marketing on Brand Awareness, as the corresponding $\mathrm{P}$-value is greater than $0.05(\mathrm{P}$-value $=0.912)$.

There is a significant impact of Cause-Related Event Marketing on Brand Awareness, as the corresponding $\mathrm{P}$-value is less than 0.05 ( $\mathrm{P}$-value $=0.008)$. Also, there is a positive impact of Cause-Related Experiential Marketing on Brand Awareness, as the corresponding estimate is greater than zero (Estimate = 0.192)

There is an insignificant impact of Transaction-Based CRM on Brand Awareness, as the corresponding $\mathrm{P}$-value is greater than $0.05(\mathrm{P}$-value $=0.178)$.

Furthermore, the R square is 0.183 , which means $18.3 \%$ of the variation in the Brand Awareness can be explained by the CRM Strategies.

Therefore, H2.3 "CRM Strategies influence the Brand Awareness" is partially supported.

The correlation matrix for the relationship between CRM Strategies; Sponsorship-Linked Marketing, Transaction-Based CRM, Cause-Related Experiential Marketing, Cause-Related Event Marketing, and Brand Association. It was observed that:

There is a significant relationship between Sponsorship-Linked Marketing and Brand Association, as the corresponding $\mathrm{P}$-value is less than 0.05 (P-value $=$ 0.000). Also, there is a positive moderate relationship between Sponsorship-Linked Marketing and Brand Association, as the corresponding correlation coefficient lies between 0.3 and $0.6(r=0.322)$.

Table 4. SEM analysis of CRM strategies on brand awareness.

\begin{tabular}{|c|c|c|c|c|c|}
\hline & & & Estimate & $\mathrm{P}$ & $\mathrm{R}^{2}$ \\
\hline Brand Image & $<---$ & Cause-Related Experiential Marketing & 0.206 & 0.001 & \multirow{4}{*}{0.171} \\
\hline Brand Image & $<---$ & Sponsorship-Linked Marketing & 0.160 & 0.116 & \\
\hline Brand Image & $<---$ & Cause-Related Event Marketing & -0.012 & 0.876 & \\
\hline Brand Image & $<---$ & Transaction-Based CRM & 0.036 & 0.514 & \\
\hline
\end{tabular}


There is a significant relationship between Transaction-Based CRM and Brand Association, as the corresponding $\mathrm{P}$-value is less than 0.05 ( $\mathrm{P}$-value $=0.000$ ). Also, there is a positive relationship between Transaction-Based CRM and Brand Association, as the corresponding correlation coefficient lies between 0.3 and 0.6 $(\mathrm{r}=0.318)$.

There is a significant relationship between Cause-Related Event Marketing and Brand Association, as the corresponding $\mathrm{P}$-value is less than 0.05 ( $\mathrm{P}$-value = 0.000). Also, there is a positive moderate relationship between Cause-Related Event Marketing and Brand Association, as the corresponding correlation coefficient lies between 0.3 and $0.6(\mathrm{r}=0.347)$.

There is a significant relationship between Cause-Related Experiential Marketing and Brand Association, as the corresponding P-value is less than 0.05 (P-value $=0.000)$. Also, there is a positive moderate relationship between Cause-Related Experiential Marketing and Brand Association, as the corresponding correlation coefficient lies between 0.3 and $0.6(r=0.380)$.

Table 5 shows the SEM analysis for the impact of the CRM Strategies; Sponsorship-Linked Marketing, Transaction-Based CRM, Cause-Related Experiential Marketing, and Cause-Related Event Marketing on Brand Association. It could be observed that:

There is a significant impact of Cause-Related Experiential Marketing on Brand Association, as the corresponding $\mathrm{P}$-value is less than $0.05(\mathrm{P}$-value $=0.003$ ). Also, there is a positive impact of Cause-Related Experiential Marketing on Brand Association, as the corresponding estimate is greater than zero (Estimate $=0.184)$.

There is an insignificant impact of Sponsorship-Linked Marketing on Brand Association, as the corresponding $\mathrm{P}$-value is greater than 0.05 ( $\mathrm{P}$-value $=0.247$ ).

There is an insignificant impact of Cause-Related Event Marketing on Brand Association, as the corresponding $\mathrm{P}$-value is greater than $0.05(\mathrm{P}$-value $=0.252)$.

There is an insignificant impact of Transaction-Based CRM on Brand Association, as the corresponding $\mathrm{P}$-value is greater than $0.05(\mathrm{P}$-value $=0.230)$.

Furthermore, the R square is 0.224 , which means $22.4 \%$ of the variation in the Brand Association can be explained by the CRM Strategies.

Therefore, H2.4 "CRM Strategies influence the Brand Association" is partially supported.

Table 5. SEM analysis of CRM strategies on brand association.

\begin{tabular}{cccccc}
\hline & & & Estimate & $\mathrm{P}$ & $\mathrm{R}^{2}$ \\
\hline Brand Association & $<---$ & Cause-Related Experiential Marketing & 0.184 & 0.003 & \\
Brand Association & $<---$ & Sponsorship-Linked Marketing & 0.114 & 0.247 & \\
Brand Association & $<---$ & Cause-Related Event Marketing & 0.082 & 0.252 & 0.224 \\
Brand Association & $<---$ & Transaction-Based CRM & 0.064 & 0.230 & \\
\hline
\end{tabular}


The correlation matrix for the relationship between CRM Strategies; Sponsorship-Linked Marketing, Transaction-Based CRM, Cause-Related Experiential Marketing, Cause-Related Event Marketing, and Brand Loyalty. It was observed that:

There is a significant relationship between Sponsorship-Linked Marketing and Brand Loyalty, as the corresponding $\mathrm{P}$-value is less than 0.05 ( $\mathrm{P}$-value $=0.000$ ). Also, there is a positive moderate relationship between Sponsorship-Linked Marketing and Brand Loyalty, as the corresponding correlation coefficient lies between 0.3 and $0.6(r=0.341)$.

There is a significant relationship between Transaction-Based CRM and Brand Loyalty, as the corresponding $\mathrm{P}$-value is less than 0.05 ( $\mathrm{P}$-value $=0.000)$. Also, there is a positive relationship between Transaction-Based CRM and Brand Loyalty, as the corresponding correlation coefficient lies between 0.3 and $0.6(r=0.287)$.

There is a significant relationship between Cause-Related Event Marketing and Brand Loyalty, as the corresponding $\mathrm{P}$-value is less than 0.05 ( $\mathrm{P}$-value = 0.000). Also, there is a positive moderate relationship between Cause-Related Event Marketing and Brand Loyalty, as the corresponding correlation coefficient lies between 0.3 and $0.6(r=0.294)$.

There is a significant relationship between Cause-Related Experiential Marketing and Brand Loyalty, as the corresponding $\mathrm{P}$-value is less than 0.05 (P-value $=0.000)$. Also, there is a positive moderate relationship between Cause-Related Experiential Marketing and Brand Loyalty, as the corresponding correlation coefficient lies between 0.3 and $0.6(\mathrm{r}=0.320)$.

Table 6 shows the SEM analysis for the impact of the CRM Strategies; Sponsorship-Linked Marketing, Transaction-Based CRM, Cause-Related Experiential Marketing, and Cause-Related Event Marketing on Brand Loyalty. It could be observed that:

There is a significant impact of Cause-Related Experiential Marketing on Brand Loyalty, as the corresponding $\mathrm{P}$-value is less than 0.05 ( $\mathrm{P}$-value $=0.030$ ). Also, there is a positive impact of Cause-Related Experiential Marketing on Brand Loyalty, as the corresponding estimate is greater than zero (Estimate $=0.146$ ).

There is an insignificant impact of Sponsorship-Linked Marketing on Brand Loyalty, as the corresponding $\mathrm{P}$-value is greater than $0.05(\mathrm{P}$-value $=0.239)$.

There is an insignificant impact of Cause-Related Event Marketing on Brand Loyalty, as the corresponding $\mathrm{P}$-value is greater than 0.05 ( $\mathrm{P}$-value $=0.462$ ).

Table 6. SEM analysis of CRM strategies on brand loyalty.

\begin{tabular}{cccccc}
\hline & & & Estimate & $\mathrm{P}$ & $\mathrm{R}^{2}$ \\
\hline Brand Loyalty & $<---$ & Cause-Related Experiential Marketing & 0.146 & 0.030 & \\
Brand Loyalty & $<---$ & Sponsorship-Linked Marketing & 0.127 & 0.239 & \\
Brand Loyalty & $<---$ & Cause-Related Event Marketing & 0.058 & 0.462 & 0.128 \\
Brand Loyalty & $<---$ & Transaction-Based CRM & 0.015 & 0.801 & \\
\hline
\end{tabular}


There is an insignificant impact of Transaction-Based CRM on Brand Loyalty, as the corresponding $\mathrm{P}$-value is greater than $0.05(\mathrm{P}$-value $=0.801)$.

Furthermore, the R square is 0.128 , which means $12.8 \%$ of the variation in the Brand Loyalty can be explained by the CRM Strategies.

Therefore, the H2.5 "CRM Strategies influence the Brand Loyalty" is partially supported.

The correlation matrix for the relationship between CRM Strategies; Sponsorship-Linked Marketing, Transaction-Based CRM, Cause-Related Experiential Marketing, Cause-Related Event Marketing, and Perceived Quality. It was observed that:

There is a significant relationship between Sponsorship-Linked Marketing and Perceived Quality, as the corresponding $\mathrm{P}$-value is less than 0.05 ( $\mathrm{P}$-value $=$ 0.000 ). Also, there is a positive moderate relationship between Sponsorship-Linked Marketing and Perceived Quality, as the corresponding correlation coefficient lies between 0.3 and $0.6(r=0.349)$.

There is a significant relationship between Transaction-Based CRM and Perceived Quality, as the corresponding $\mathrm{P}$-value is less than 0.05 ( $\mathrm{P}$-value $=0.000)$. Also, there is a positive relationship between Transaction-Based CRM and Perceived Quality, as the corresponding correlation coefficient lies between 0.3 and $0.6(\mathrm{r}=0.304)$.

There is a significant relationship between Cause-Related Event Marketing and Perceived Quality, as the corresponding P-value is less than 0.05 (P-value $=$ 0.000). Also, there is a positive moderate relationship between Cause-Related Event Marketing and Perceived Quality, as the corresponding correlation coefficient lies between 0.3 and $0.6(\mathrm{r}=0.294)$.

There is a significant relationship between Cause-Related Experiential Marketing and Perceived Quality, as the corresponding P-value is less than 0.05 $(\mathrm{P}$-value $=0.000)$. Also, there is a positive moderate relationship between Cause-Related Experiential Marketing and Perceived Quality, as the corresponding correlation coefficient lies between 0.3 and $0.6(r=0.409)$.

Table 7 shows the SEM analysis for the impact of the CRM Strategies; Sponsorship-Linked Marketing, Transaction-Based CRM, Cause-Related Experiential Marketing, and Cause-Related Event Marketing on Perceived Quality. It could be observed that:

There is a significant impact of Cause-Related Experiential Marketing on Perceived Quality, as the corresponding P-value is less than 0.05 ( $\mathrm{P}$-value $=0.000$ ). Also, there is a positive impact of Cause-Related Experiential Marketing on Perceived Quality, as the corresponding estimate is greater than zero (Estimate $=$ 0.257).

There is a significant impact of Sponsorship-Linked Marketing on Perceived Quality, as the corresponding P-value is less than $0.05(\mathrm{P}$-value $=0.046)$. Also, there is a positive impact of Cause-Related Experiential Marketing on Perceived Quality, as the corresponding estimate is greater than zero (Estimate $=0.196$ ). 
Table 7. The SEM analysis of CRM strategies on perceived quality.

\begin{tabular}{|c|c|c|c|c|c|c|}
\hline \multirow[t]{2}{*}{ Model } & \multicolumn{2}{|c|}{$\begin{array}{l}\text { Unstandardized } \\
\text { Coefficients }\end{array}$} & \multirow{2}{*}{$\begin{array}{c}\text { Standardized } \\
\text { Coefficients } \\
\text { Beta }\end{array}$} & \multirow[t]{2}{*}{$\mathbf{t}$} & \multirow[t]{2}{*}{ Sig. } & \multirow[t]{2}{*}{ R Square } \\
\hline & B & Std. Error & & & & \\
\hline (Constant) & 0.722 & 0.361 & & 1.999 & 0.047 & \\
\hline Financial standards & 0.724 & 0.082 & 0.554 & 8.833 & 0.000 & \\
\hline Customer perspectives & -0.127 & 0.093 & -0.139 & -1.356 & 0.177 & 0.358 \\
\hline Internal operation & 0.132 & 0.092 & 0.145 & 1.435 & 0.153 & \\
\hline Learning and development & 0.097 & 0.073 & 0.112 & 1.324 & 0.187 & \\
\hline
\end{tabular}

${ }^{\mathrm{a} D e p e n d e n t ~ V a r i a b l e: ~ f i n a n c i a l ~ p e r f o r m a n c e . ~}$

There is an insignificant impact of Cause-Related Event Marketing on Perceived Quality, as the corresponding P-value is greater than $0.05(\mathrm{P}$-value $=0.978)$.

There is an insignificant impact of Transaction-Based CRM on Perceived Quality, as the corresponding $\mathrm{P}$-value is greater than 0.05 ( $\mathrm{P}$-value $=0.936$ ).

Furthermore, the $\mathrm{R}$ square is 0.222 , which means $22.2 \%$ of the variation in the Perceived Quality can be explained by the CRM Strategies.

Therefore, H2.6 "CRM Strategies influence the Perceived Quality” is partially supported.

\subsection{The Third Hypothesis: The Relationship between Brand Equity, Brand Loyalty, Brand Image, Brand Association, Brand Awareness, Perceived Quality, and Behavioral Intention}

This section investigates the relationship between Brand Equity, Brand Loyalty, Brand Image, Brand Association, Brand Awareness, Perceived Quality, and Behavioral Intention. The correlation matrix for the relationship between CRM Strategies; Sponsorship-Linked Marketing, Transaction-Based CRM, Cause-Related Experiential Marketing, Cause-Related Event Marketing, and Behavioral Intention. It was observed that:

There is a significant relationship between Brand Equity and Behavioral Intention, as the corresponding $\mathrm{P}$-value is less than 0.05 ( $\mathrm{P}$-value $=0.000)$. Also, there is a positive moderate relationship between Brand Equity and Behavioral Intention, as the corresponding correlation coefficient lies between 0.3 and $0.6(\mathrm{r}$ $=0.582$ ).

There is a significant relationship between Brand Loyalty and Behavioral Intention, as the corresponding $\mathrm{P}$-value is less than 0.05 ( $\mathrm{P}$-value $=0.000)$. Also, there is a positive relationship between Brand Image and Behavioral Intention, as the corresponding correlation coefficient lies between 0.6 and $0.8(\mathrm{r}=0.683)$.

There is a significant relationship between Brand Image and Behavioral Intention, as the corresponding $\mathrm{P}$-value is less than 0.05 ( $\mathrm{P}$-value $=0.000)$. Also, there is a positive moderate relationship between Brand Image and Behavioral Inten- 
tion, as the corresponding correlation coefficient lies between 0.6 and $0.8(\mathrm{r}=$ $0.689)$.

There is a significant relationship between Brand Association and Behavioral Intention, as the corresponding $\mathrm{P}$-value is less than 0.05 ( $\mathrm{P}$-value $=0.000)$. Also, there is a positive moderate relationship between Brand Association and Behavioral Intention, as the corresponding correlation coefficient lies between 0.6 and $0.8(\mathrm{r}=0.612)$.

There is a significant relationship between Brand Awareness and Behavioral Intention, as the corresponding $\mathrm{P}$-value is less than 0.05 ( $\mathrm{P}$-value $=0.000)$. Also, there is a positive moderate relationship between Brand Awareness and Behavioral Intention, as the corresponding correlation coefficient lies between 0.6 and $0.8(\mathrm{r}=0.720)$.

There is a significant relationship between Perceived Quality and Behavioral Intention, as the corresponding $\mathrm{P}$-value is less than $0.05(\mathrm{P}$-value $=0.000)$. Also, there is a positive moderate relationship between Perceived Quality and Behavioral Intention, as the corresponding correlation coefficient lies between 0.6 and $0.8(\mathrm{r}=0.756)$.

Table 8 shows the SEM analysis for the impact of the Brand Equity, Brand Loyalty, Brand Image, Brand Association, Brand Awareness, and Perceived Quality on Behavioral Intention. It could be observed that:

There is an insignificant impact of Brand Equity on Behavioral Intention, as the corresponding $\mathrm{P}$-value is greater than $0.05(\mathrm{P}$-value $=0.483)$.

There is a significant impact of Brand Loyalty on Behavioral Intention, as the corresponding $\mathrm{P}$-value is less than $0.05(\mathrm{P}$-value $=0.000)$. Also, there is a positive impact of Brand Loyalty on Behavioral Intention, as the corresponding estimate is greater than zero (Estimate $=0.355$ ).

There is an insignificant impact of Brand Image on Behavioral Intention, as the corresponding $\mathrm{P}$-value is greater than $0.05(\mathrm{P}$-value $=0.503)$.

There is an insignificant impact of Brand Awareness on Behavioral Intention, as the corresponding $\mathrm{P}$-value is greater than $0.05(\mathrm{P}$-value $=0.360)$.

Table 8. The SEM analysis of brand equity, brand loyalty, brand image, brand association, brand awareness, and perceived quality on behavioral intention.

\begin{tabular}{|c|c|c|c|c|c|}
\hline & & & Estimate & $\mathrm{P}$ & $\mathrm{R}^{2}$ \\
\hline Behavioral Intention & $<--$ & Brand Equity & -0.067 & 0.483 & \\
\hline Behavioral Intention & $<---$ & Brand Loyalty & 0.355 & $* * *$ & \\
\hline \multirow[t]{2}{*}{ Behavioral Intention } & $<--$ & Brand Image & -0.065 & 0.503 & \\
\hline & & & & & 0.827 \\
\hline Behavioral Intention & $<---$ & Brand Awareness & 0.040 & 0.360 & \\
\hline Behavioral Intention & & Perceived Quality & 0.587 & $* * *$ & \\
\hline Behavioral Intention & & Brand Association & 0.160 & 0.020 & \\
\hline
\end{tabular}


There is a significant impact of Perceived Quality on Behavioral Intention, as the corresponding $\mathrm{P}$-value is less than 0.05 ( $\mathrm{P}$-value $=0.000)$. Also, there is a positive impact of Perceived Quality on Behavioral Intention, as the corresponding estimate is greater than zero (Estimate $=0.587$ ).

There is a significant impact of Brand Association on Behavioral Intention, as the corresponding $\mathrm{P}$-value is less than 0.05 ( $\mathrm{P}$-value = 0.020). Also, there is a positive impact of Brand Association on Behavioral Intention, as the corresponding estimate is greater than zero (Estimate $=0.160$ ).

Furthermore, the R square is 0.827 , which means $82.7 \%$ of the variation in the Behavioral Intention can be explained by the model.

Therefore, based on the previous results it could be noted that:

H3.1: "Brand Equity influence the Behavioral Intention" is not supported.

H3.2: "Brand Image influence the Behavioral Intention" is not supported.

H3.3: "Brand Awareness influence the Behavioral Intention" is not supported.

H3.4: "Brand Association influence the Behavioral Intention" is supported.

H3.5: "Brand Loyalty influence the Behavioral Intention" is supported.

H3.6: "Perceived Quality influence the Behavioral Intention" is supported.

\section{Conclusion, Recommendation and Limitations}

Corporate social responsibility is considered one of the main elements in forming companies' reputation, participating in realistic and effective strategies to provide social services, and enhancing the organization's public reputation, which facilitates the organization's management mechanisms and increases its ability to attract new clients and increase its market share. The social can enhance the company's value in the financial market and raise its ability to access capital. In addition, corporate social responsibility is one of the main elements in forming companies' reputation, participating in realistic and effective strategies to provide social services, enhancing the organization's public reputation, which facilitates the organization's management mechanisms and increases its ability to attract new clients and increase its market share.

Therefore, this study investigates the relationship between CRM Strategies and Behavioral Intention with the mediation role of Brand Equity, Brand Image, Brand Loyalty, Brand Association, Brand Awareness, and Perceived Quality. Thus, literature had been reviewed to find out the research hypotheses and define the research gap in literature. Accordingly, the methodological philosophy and approach had been selected for answering the research questions. According to the results, it is noticed that the hypothesis, "CRM Strategies (Sponsorship-Linked Marketing, Transaction-Based CRM, Cause-Related Experiential Marketing, and Cause-Related Event Marketing) has a direct influence on Behavioral Intention" is partially supported as;

- There is a significant impact of Cause-Related Experiential Marketing on Behavioral Intention, as the corresponding $\mathrm{P}$-value is less than 0.05.

- There is an insignificant impact of Sponsorship-Linked Marketing on Beha- 
vioral Intention, as the corresponding P-value is greater than 0.05 .

- There is an insignificant impact of Cause-Related Event Marketing on Behavioral Intention, as the corresponding P-value is greater than 0.05 .

- There is an insignificant impact of Transaction-Based CRM on Behavioral Intention, as the corresponding P-value is greater than 0.05 .

\subsection{Recommendations}

This paper provides some recommendations for the coming researchers. The recommendations include current recommendations and future recommendations. Those recommendations are provided according to the results that the research reached that will help in developing that will CRM Strategies affect significantly Behavioral Intention.

- Inclusion of social responsibility in the mission, vision, philosophy and culture of companies, as well as within the rules and principles of government companies and institutions, and considering social responsibility among the responsibilities of the executive management and under its supervision, within the plans and policies of the companies' board of directors, as well as this responsibility must be included in the communication, education and training programs of the company, and that responsibility should be included social recognition of the employee's value and giving him adequate incentives, and for the company to develop periodic reports, and to conduct a review of the extent to which it observes its social responsibilities.

- The need to work on developing a set of standards or indicators by the concerned authorities in Egypt, such as the Managers Center for Social Responsibility affiliated with the Ministry of Investment, in order to compare and evaluate the social role of companies, and provided that these standards are practically applicable, socially acceptable and taken by companies to measure them.

- The need to focus on educating and educating small-sized companies about the importance of practicing social responsibility and how it is in relation to the size of the company and how social responsibility helps develop the company and benefit it financially. As companies are small in size in Egypt, they rarely play a social role and do not have sufficient awareness of practicing it. In addition to the orientation towards novice entrepreneurs to instill the importance of social responsibility in their minds and that training programs for entrepreneurship and self-employment skills include training on social responsibility to ensure that there is a broad base of social responsibility in the future business sector.

- The introduction of the field of social responsibility within the general policy of the state with the passage of a law that regulates the scope of corporate social responsibility as it is an area that helps in eliminating many of the problems that society suffers from.

- Creating a formal institutional organizational framework concerned with so- 
cial responsibility, monitoring and developing it, along with developing methods and programs for evaluating the social performance of institutions.

- Companies are required to submit an annual or seasonal report on social responsibility, and civil society and the state are allowed to review it in order to ensure transparency.

- Holding training courses for the departments of the relevant companies, which contributes to more clarity of marketing strategies and how they affect consumer behavior.

\subsection{Limitations}

As any other research, this research has many limitations. First, the limitation of the sampling as the study sample was a random sample of Graduates who represented $29.8 \%$ from sample and undergraduates who represented $70.1 \%$ from sample of private education sector. So, the researcher suggests increasing the sample size and to make more researches on other public institutions. The researcher also suggests making other studies on other sectors to see if the same results will be conducted or no.

The study also limited its research on Egypt only as a developing country. Therefore, the researcher suggested that the future researches have to measure the variables of the study in other developing countries. The researcher also recommends making comparison between developed and developing countries.

Finally, the study also had a limitation regarding the timing, as the data collected for the study including a limited duration of time so the study recommends for the future researches to include a wider period.

\section{Conflicts of Interest}

The authors declare no conflicts of interest.

\section{References}

[1] McPherson, S. (2017) 6 CSR Trends to Watch in 2017. https://www.forbes.com/sites/susanmcpherson/2017/01/19/6-csr-trends-to-watch-i n-2017/\#415566b1cc45

[2] Subrahmanyan, S. (2004) Effects of Price Premium and Product Type on the Choice of Cause-Related Brands: A Singapore Perspective. Journal of Product \& Brand Management, 13, 116-124. https://doi.org/10.1108/10610420410529744

[3] Belch, G.E. and Belch, M.A. (1998) Introduction to Advertising and Promotion.

[4] Rossiter, J.R. and Danaher, P.J. (1998) Advanced Media Planning. Springer Science \& Business Media, Berlin. https://doi.org/10.1007/978-1-4419-8738-9

[5] Lafferty, B.A. and Goldsmith, R.E. (1999) Corporate Credibility's Role in Consumers' Attitudes and Purchase Intentions When a High versus a Low Credibility Endorser Is Used in the Ad. Journal of Business Research, 44, 109-116. https://doi.org/10.1016/S0148-2963(98)00002-2

[6] Mitchell, A.A. and Olson, J.C. (1981) Are Product Attribute Beliefs the Only Mediator of Advertising Effects on Brand Attitude? Journal of Marketing Research, 18, 318-332. https://doi.org/10.1177/002224378101800306 
[7] Ptacek, J.J. and Salazar, G. (1997) Enlightened Self-Interest: Selling Business on the Benefits of Cause-Related Marketing. Nonprofit World, 15, 9-15.

[8] Sen, S. and Morwitz, V.G. (1996) Consumer Reactions to a Provider's Position on Social Issues: The Effect of Varying Frames of Reference. Journal of Consumer Psychology, 5, 27-48. https://doi.org/10.1207/s15327663jcp0501_02

[9] Ross III, J.K., Patterson, L.T. and Stutts, M.A. (1992) Consumer Perceptions of Organizations That Use Cause-Related Marketing. Journal of the Academy of Marketing Science, 20, 93-97. https://doi.org/10.1007/BF02723480

[10] Smith, S.M. and Alcorn, D.S. (1991) Cause Marketing: A New Direction in the Marketing of Corporate Responsibility. Journal of Consumer Marketing, 8, 19-35. https://doi.org/10.1108/07363769110035054

[11] Shabbir, S., Kaufmann, H.R., Ahmad, I. and Qureshi, I.M. (2010) Cause Related Marketing Campaigns and Consumer Purchase Intentions: The Mediating Role of Brand Awareness and Corporate Image. African Journal of Business Management, 4, 1229-1235.

[12] Melero, I. and Montaner, T. (2016) Cause-Related Marketing: An Experimental Study about How the Product Type and the Perceived Fit May Influence the Consumer Response. European Journal of Management and Business Economics, 25, 161-167. https://doi.org/10.1016/j.redeen.2016.07.001

[13] Bakhshizadeh Baraj, K. (2018) The Effect of Cause Involvement and Skepticism about Cause Related Marketing on Consumer Attitudes toward Brand, Advertising and Purchase Intention. Brand Management, 5, 82-53.

[14] Feminingtyas, A.M. and Mayangsari, L. (2020) The Influence of Cause Related Marketing towards Purchase Intention in Local Fashion Brands Indonesia. International Conference on Economics, Business and Economic Education 2019, Volume 2020, 1106-1119.

[15] Saberi, H. and Karsalari, A.R. (2014) The Interactive Effects of Cause Related Marketing Campaigns, Perceptual Brand Equity Dimensions and Cultural Values on Consumer Purchase Intentions. International Journal of Academic Research in Accounting, Finance and Management Sciences, 4, 117-126.

[16] Hannantyas, A.A., Yulianto, E. and Mawardi, M.K. (2016) The Role of Cause-Related Marketing on Multinational Corporate Reputation, Brand Image, and Purchase Intention in Indonesia and Thailand (Study Case on the Body Shop against Animal Testing Campaign). Jurnal Administrasi Bisnis, 33, 11-17.

[17] Mao, L.L. and Zhang, J. (2018) Branding through Sponsorship-Linked Marketing: A Case of Chinese Sports Apparel and Equipment Brand "Li Ning". In: Digital Marketing and Consumer Engagement: Concepts, Methodologies, Tools, and Applications, IGI Global, Hershey, 191-214. https://doi.org/10.4018/978-1-5225-5187-4.ch011

[18] Moradi, H. and Zarei, A. (2011) The Impact of Brand Equity on Purchase Intention and Brand Preference-The Moderating Effects of Country of Origin Image. Australian Journal of Basic and Applied Sciences, 5, 539-545.

[19] Shukla, P. (2011) Impact of Interpersonal Influences, Brand Origin and Brand Image on Luxury Purchase Intentions: Measuring Interfunctional Interactions and a Cross-National Comparison. Journal of World Business, 46, 242-252. https://doi.org/10.1016/j.jwb.2010.11.002

[20] Naeini, A., Azali, P.R. and Tamaddoni, K.S. (2015) Impact of Brand Equity on Purchase Intention and Development, Brand Preference and Customer Willingness to Pay Higher Prices. Management and Administrative Sciences Review, 4, 616-626. 
[21] Sasmita, J. and Suki, N.M. (2015) Young Consumers' Insights on Brand Equity: Effects of Brand Association, Brand Loyalty, Brand Awareness, and Brand Image. International Journal of Retail \& Distribution Management, 43, 276-292.

https://doi.org/10.1108/IJRDM-02-2014-0024 